\title{
Exocytosis of a Single Bovine Adrenal Chromaffin Cell: The Electrical and Morphological Studies
}

\author{
Chia-Chang Tsai, ${ }^{\dagger}$ Chih-Cheng Yang, ${ }^{\ddagger}$ Po-Yuan Shih, ${ }^{\ddagger}$ Cen-Shawn Wu, ${ }^{\S}$ Chii-Dong Chen," \\ Chien-Yuan Pan,*** and Yit-Tsong Chen*, $\uparrow, \perp$ \\ Institute of Atomic and Molecular Sciences, Academia Sinica, P.O. Box 23-166, Taipei 106, Taiwan, \\ Department of Life Science and Institute of Zoology, National Taiwan University, Taipei 106, Taiwan, \\ Department of Physics, Jin-De Campus, National Changhua University of Education, Changhua 500, Taiwan, \\ Institute of Physics, Academia Sinica, Nankang, Taipei 115, Taiwan, and Department of Chemistry, \\ National Taiwan University, Taipei 106, Taiwan
}

Received: April 7, 2008; Revised Manuscript Received: May 19, 2008

\begin{abstract}
Exocytosis of a single bovine adrenal chromaffin cell, triggered by histamine stimulation, was investigated via the electric responses detected with single-walled carbon-nanotube field-effect transistors (SWCNT-FET) and the morphological changes acquired by atomic force microscopy (AFM). Secretion of chromogranin A (CgA), stored in the vesicles of a single chromaffin cell, can be monitored in situ by the antibody against CgA (CgA-antibody) functionalized on the SWCNT-FET devices. The SWCNT-FET can further discriminate the amount of released $\mathrm{CgA}$ with different levels of histamine stimulations. The AFM morphological studies on a chromaffin cell indicate that the depression structures on the cell surface, caused by the histamineevoked exocytotic fusion pores, appeared much more frequently than those without histamine stimulation or with the pretreatment of mepyramine before histamine stimulation. The vesicle diameters are about $50 \mathrm{~nm}$ calculated from the obtained three-dimensional AFM images. In comparison, the fusion pores of chromaffin cells stimulated by high- $\mathrm{K}^{+}$buffer solution were also investigated to have a wider-ranging distribution of vesicle diameters of 60-260 $\mathrm{nm}$. This work demonstrates that the combination of novel techniques, SWCNTFET and AFM, can provide further insights into the fundamental properties of exocytosis in neuroendocrine cells.
\end{abstract}

\section{Introduction}

The development of nanotechnology offers novel tools to characterize the activities of single molecules and individual living cells with high spatial/temporal resolution. These tools allow researchers to obtain more detailed information than traditional approaches in life science research. Exocytosis is an important physiological process that a secretory vesicle (SV) undergoes trafficking, priming, docking, and fusion to the cell membrane. ${ }^{1,2}$ Thereafter, soluble proteins or bioactive molecules stored inside the vesicle are released to the extracellular environment for signal transmission. Biochemical studies have identified a set of proteins involved in this process; however, the kinetics for the formation of fusion pores is still obscure. To further characterize this mechanism, single-walled carbonnanotube field-effect transistors (SWCNT-FET) and atomic force microscopy (AFM) have been applied in this study to investigate the exocytotic process in single chromaffin cells isolated from bovine adrenal gland.

CNT-FET ${ }^{3-5}$ and nanowire-based field-effect transistors $(\mathrm{NW}-\mathrm{FET})^{6-9}$ have been well developed for biosensory applications because of their selectivity, sensitivity, real-time, and label-

* Corresponding authors. Y.-T.C.: e-mail, ytchen@pub.iams.sinica.edu.tw; fax, (+886) 2-2362-0200. C.-Y.P.: e-mail, cypan@ntu.edu.tw; fax, $(+886)$ 2-2363-6837.

$\dagger$ Institute of Atomic and Molecular Sciences, Academia Sinica.

$¥$ Department of Life Science and Institute of Zoology, National Taiwan University.

$\S$ National Changhua University of Education.

"Institute of Physics, Academia Sinica.

$\perp$ Department of Chemistry, National Taiwan University. free detection capabilities. Binding of proteins to the corresponding binding receptors functionalized on the CNT-FET or NW-FET surface can cause prominent change in the FET conductance. Our previous study has demonstrated that the release of chromogranin $\mathrm{A}(\mathrm{CgA}),{ }^{10}$ a soluble protein stored in $\mathrm{SV}$, from living neurons upon glutamate stimulation can be detected by SWCNT-FET modified with the antibody $(\mathrm{Ab})$ against $\mathrm{CgA}$ (termed $\mathrm{CgA}-\mathrm{Ab} / \mathrm{SWCNT}-\mathrm{FET}$ ). ${ }^{5}$ The detection limit of the $\mathrm{CgA}$ peptides by $\mathrm{CgA}-\mathrm{Ab} / \mathrm{SWCNT}$-FET can be as low as $1 \mathrm{nM}$. To further exploit the sensory applicabilities of the FET devices for biological research, we apply $\mathrm{CgA}-\mathrm{Ab} /$ SWCNT-FET in this study to detect the release of CgA from cultured single bovine chromaffin cells.

In the study of cellular exocytosis, several biochemical methods have been widely used to investigate the exocytotic characteristics. For examples, electron microscopy provides high-resolution images about the vesicle fusion and recycling, ${ }^{11}$ although the sample should be fixed in the examination. Amperometry, ${ }^{12}$ which oxidizes the catecholamine (CA) released from single vesicles, reveals the kinetics of exocytosis, but little information about the fusion pore. Fluorescent proteins in combination with confocal microscopy ${ }^{13}$ or total internal reflection microscopy ${ }^{14}$ were applied recently to investigate the vesicle recycling process. However, because of the weak fluorescence signals, these fluorescent images are usually of low spatial and temporal resolutions. Although CNT-FET/NW-FET is a very sensitive biosensor with many merits in monitoring the proteins released from live cells, it can not be used to observe the fusion pore opening. 

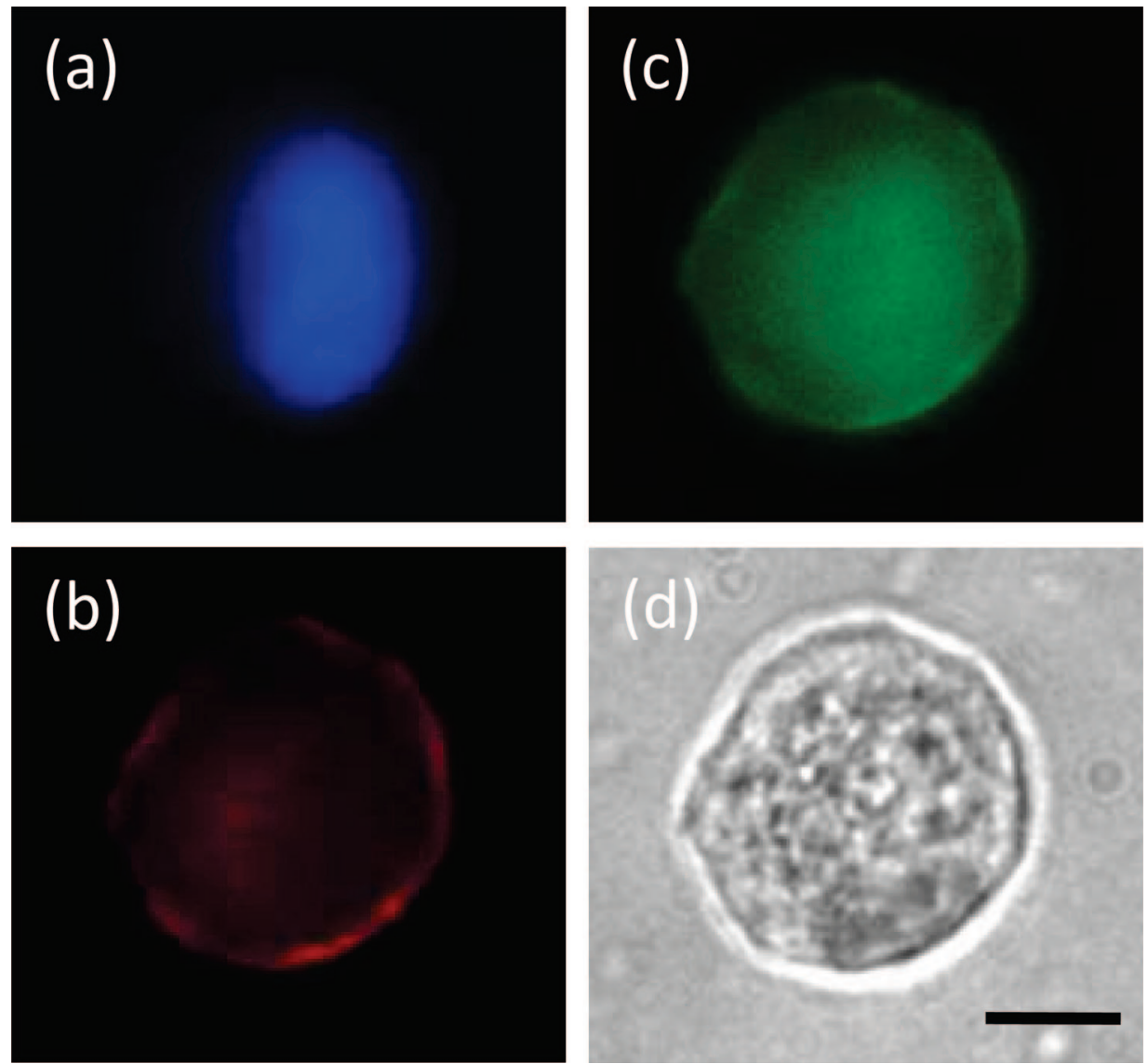

Figure 1. Localization of $\mathrm{CgA}$ in a bovine adrenal chromaffin cell. The cell was fixed with formaldehyde and stained with (a) DAPI and (b) rhodamine-conjugated phalloidin to label the nucleus and F-Actin, respectively. (c) Distribution of CgA visualized with specific antibody. (d) Bright field image of the cell. The images were observed in a Leica epifluorescence microscope $(100 \times$, NA1.45, oil objective) equipped with a CCD camera. The scale bar indicates $5 \mu \mathrm{m}$.

AFM, which has spatial resolution comparable to electron microscopy, can provide a true three-dimensional (3D) surface profile of a sample. Additionally, AFM has been improved to be able to monitor molecular interactions under normal physiological saline buffer and has been extensively applied to image many kinds of cells for morphological studies ${ }^{15-18}$ as well as electrophysiological ${ }^{19}$ and biochemical ${ }^{20}$ investigations. With AFM imaging, Jena's group ${ }^{18}$ has demonstrated that there are lots of circular pits of 500-2000 nm in diameter, containing smaller depressions of $100-180 \mathrm{~nm}$ in diameter on the surface of pancreatic $\beta$-cells. Under electron microscopic investigations, the vesicle sizes of $\beta$-cells were revealed to range from 100 to $1000 \mathrm{~nm}$. It has been reported that the depression-like structures of $120 \mathrm{~nm}$ in diameter were also found in living chromaffin cells. ${ }^{17}$ In this experiment, to further characterize the evoked exocytotic events in single bovine chromaffin cells under different stimulations, the surface of plasma membrane was scanned by AFM to identify the fusion pores formed by vesicles and plasma membrane.

\section{Experimental Section}

Cell Preparation. Chromaffin cells were prepared by digestion of bovine adrenal gland obtained from local slaughterhouses with collagenase $(0.5 \mathrm{mg} / \mathrm{mL})$ and purified by density gradient centrifugation, as previously described. ${ }^{21}$ In brief, the isolated cells were cultured in Dulbecco's modified Eagle's medium supplemented with $10 \%$ of fetal bovine serum and plated on poly-L-lysine-coated glass coverslips. Culture medium was replaced every other day. All experiments were carried out within 2-7 days after the cells were isolated.
Immunostaining. $\mathrm{CgA}$ has been shown to be stored in the $\mathrm{SV}$ close to the plasma membrane of a chromaffin cell. ${ }^{22}$ To confirm that $\mathrm{CgA}$ exists in the cells prepared in our laboratory, the distribution of $\mathrm{CgA}$ in a chromaffin cell was verified by antibody against $\mathrm{CgA}$ (Figure 1). As in the protocol described before, ${ }^{5}$ the chromaffin cells were immobilized by $3.7 \%$ formalin in phosphate buffer saline (PBS, $137 \mathrm{mM} \mathrm{NaCl}, 2.7 \mathrm{mM} \mathrm{KCl}$, $10 \mathrm{mM} \mathrm{Na}_{2} \mathrm{HPO}_{4}, 2 \mathrm{mM} \mathrm{KH} \mathrm{PO}_{4}, \mathrm{pH} 7.4$ with $\mathrm{NaOH}$ ) for 30 min and permeabilized with triton X-100 (0.5\% in PBS) for another $15 \mathrm{~min}$. Inside a cell, the nucleus was stained by DAPI (diamidino-2-phenyklindole) (Sigma-Aldrich Co.) (Figure 1a) and the F-Actin under the plasmalema was stained with rhodamine-phalloidin (Sigma-Aldrich Co.) (Figure 1b). To verify the distribution of $\mathrm{CgA}$, cells were stained with goat antiCgA antibody (Santa Cruz Biotechnology Inc., 1:200 dilution) and visualized by fluorescin isothiocyanate conjugated rabbit antigoat IgG (Sigma-Aldrich Co., 1:500 dilution) (Figure 1c). These results demonstrated that $\mathrm{CgA}$ is abundant in the cytosol, especially in a region close to the plasma membrane of a chromaffin cell.

Electrical Measurement. To measure cellular exocytosis by CgA-Ab/SWCNT-FET, a single bovine chromaffin cell was held by a micropipet with gentle suction and was moved to locate on the top of a CgA-Ab/SWCNT-FET device (Figure 2a). A real image acquired under this manipulation is shown in Figure 2b. The CgA-Ab/SWCNT-FET chip was placed on the stage of the upright microscope (Axioskop, Carl Zeiss, Inc.) alongside a micromanipulator (MO-103, Narishige Inc.). The microscope and micromanipulator were placed on an antivibration table and were covered with a Faraday cage to prevent electrical interfer- 

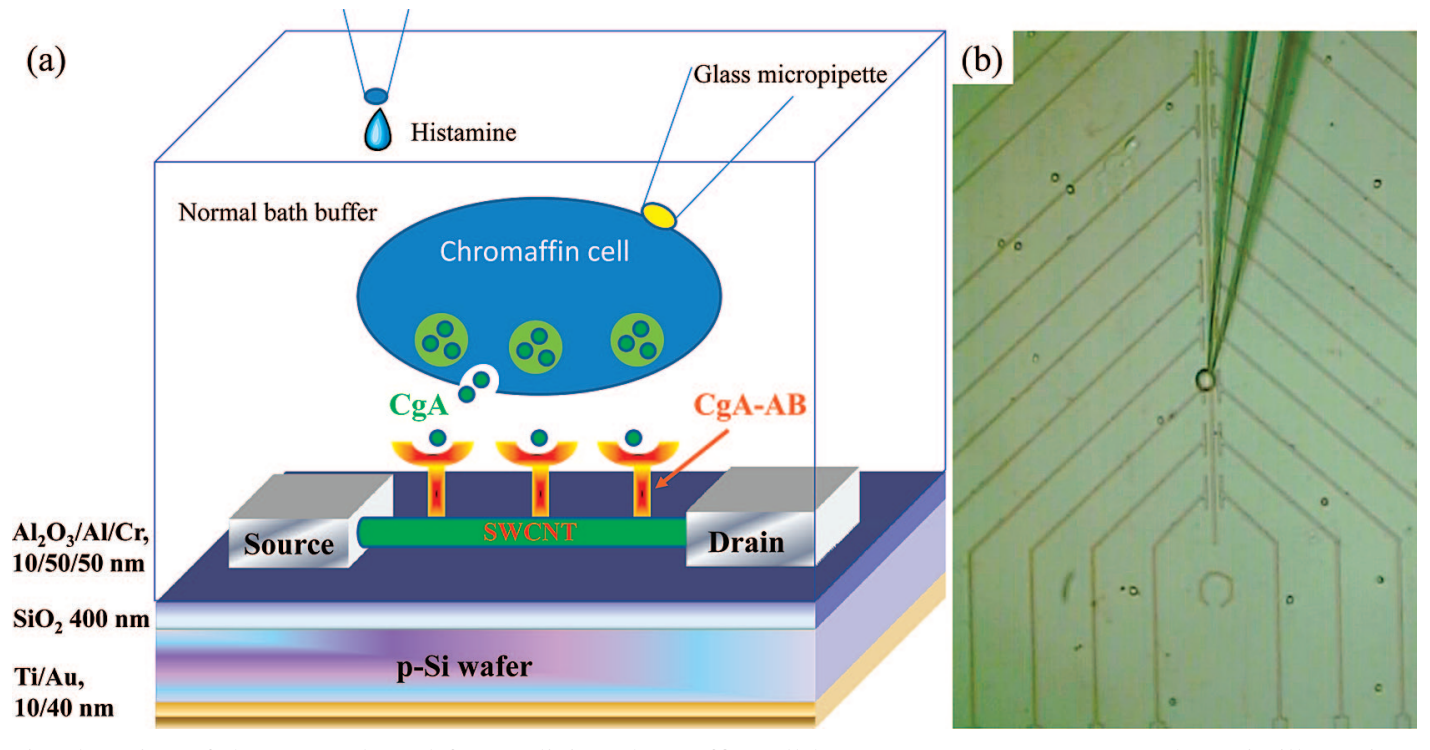

Figure 2. In situ detection of the CgA released from a living chromaffin cell by CgA/SWCNT-FET. (a) Schematic illustration of using CgA/ SWCNT-FET to monitor the CgA released from a single chromaffin cell in the histamine-evoked exocytosis. (b) Real image of a single chromaffin cell manipulated by a glass micropipet onto a $\mathrm{CgA} / \mathrm{SWCNT}$-FET device.

ence. A long-working-distance (7.9 mm) objective lens (LD PN $20 \times / 0.4$ Corr, Carl Zeiss, Inc.) was used for ease of operation in the following experiments. In the experiment, a piece of coverslip $\left(5 \times 5 \mathrm{~mm}^{2}\right)$ with some chromaffin cells cultured on it was put alongside the $\mathrm{CgA} / \mathrm{SWCNT}$-FET chip without touching the source-drain electrodes of the FET circuits. Chromaffin cells together with the $\mathrm{CgA} / \mathrm{SWCNT}$-FET were then bathed in $200 \mu \mathrm{L}$ normal bath buffer at room temperature (25 $\left.{ }^{\circ} \mathrm{C}\right)$. The glass micropipets were pulled from thin-walled glass tubes (61700, A-M Systems, Inc.) using a pipet puller (P-97, Sutter Instrument Co.) and the tips of $1-2 \mu \mathrm{m}$ in diameter were fire-polished with a microforge (MF830, Narishige Inc.). The micropipet was backfilled with pipet buffer $(130 \mathrm{mM} \mathrm{K}$ aspartate, $20 \mathrm{mM} \mathrm{KCl}, 1 \mathrm{mM} \mathrm{MgCl}, 0.1 \mathrm{mM}$ EGTA, $3 \mathrm{mM}$ $\mathrm{Na}_{2}$ ATP, $0.1 \mathrm{mM} \mathrm{Na} 2 \mathrm{GTP}$, and $20 \mathrm{mM}$ HEPES, $\mathrm{pH}$ 7.3) and mounted on the holder attached to the headstage of EPC7 amplifier (HEKA GmbH). The whole system was controlled by pClamp 6 software (Axon Inc.) and the resistance was monitored every second by applying a $10 \mathrm{mV}$ step potential command for $10 \mathrm{~ms}$. The resistance of the micropipet ranges typically from 3 to $5 \mathrm{M} \Omega$. The micropipet was moved to slightly touch a chromaffin cell and then sucked it gently until the resistance was over $1 \mathrm{G} \Omega$. The chromaffin cell was lifted and moved onto a CgA/SWCNT-FET device (Figure 2), where the $I_{\mathrm{sd}}$ was recorded at $\mathrm{V}_{\mathrm{sd}}=10 \mathrm{mV}$ by a lock-in amplifier (SR830, Stanford Research System Inc.) with modulation frequency of $17.77 \mathrm{~Hz}$.

The manufacture of SWCNT-FET devices was carried out in a clean-room environment following the previous design. ${ }^{5}$ In brief, carbon nanotubes of $2 \mathrm{~nm}$ in diameter (Thomas Swan $\&$ Co. Ltd.) were electrically contacted with a double layer of $50 \mathrm{~nm}$ thick $\mathrm{Cr}$ and $50 \mathrm{~nm}$ thick $\mathrm{Al}$ leads, which were further passivated with a $10 \mathrm{~nm}$ thick $\mathrm{Al}_{2} \mathrm{O}_{3}$ layer to avoid electric leakage to the buffer solution. The $\mathrm{Al}_{2} \mathrm{O}_{3}$ layer was formed by blowing 600 Torr of oxygen gas into the thermal evaporation chamber for 10-15 min after the thermal evaporation of $\mathrm{Al}$ leads. The electric performances of the as-fabricated SWCNTFET devices have been characterized by the source-drain current $\left(I_{\mathrm{sd}}\right)$ vs gate voltage $\left(V_{\mathrm{g}}\right)$ curves (not shown). All SWCNT-FET devices used in this work are p-type semiconductive. To functionalize $\mathrm{CgA}-\mathrm{Ab}$ on the SWCNT-FET surface, the as- fabricated SWCNT-FET devices were first treated in $7.5 \mathrm{mM}$ 1-pyrenebutanoic acid succinimidyl ester for $1 \mathrm{~h}$ and then flushed with pure methanol for $15 \mathrm{~min}$. In the surface functionalization, the solution containing 1-pyrenebutanoic acid succinimidyl ester was guided to flow through a microfluidic channel $\left(6.25 \times 0.5 \times 0.05 \mathrm{~mm}^{3}\right)$ to contact the SWCNT-FET devices driven by a syringe pump at $0.5-0.8 \mathrm{~mL} / \mathrm{h}$. Subsequently, the FET devices were incubated for $2 \mathrm{~h}$ in the PBS containing $0.2 \mu \mathrm{g} / \mathrm{mL}$ of goat $\mathrm{IgG}$ antibody against $\mathrm{CgA}$ (Santa Cruz Biotechnology Inc.). After washing off extra $\mathrm{CgA}-\mathrm{Ab}$, $\mathrm{CgA}-\mathrm{Ab} / \mathrm{SWCNT}$-FET were then incubated for $20 \mathrm{~min}$ in PBS containing $0.5 \%$ TWEEN-20, which serves as a blocking agent to prevent nonspecific bindings. The CgA-Ab/SWCNT-FET devices, finally washed with PBS buffer, were ready for the experiment of detecting cellular exocytosis.

Calcium Image. To measure cytosolic $\mathrm{Ca}^{2+}$ concentration $\left(\left[\mathrm{Ca}^{2+}\right]_{\mathrm{i}}\right)$, chromaffin cells were incubated in normal bath buffer containing $5 \mu \mathrm{M}$ fura- $2 \mathrm{AM}$ for $1 \mathrm{~h}$ at $37^{\circ} \mathrm{C}$. For the fura-2 excitation, a Lambda DG4 system (Sutter Instrument Co.) was used, which was controlled by Metafluor software (Molecular Devices Corp.). Ratiometric calcium estimates were made with the excitations at 340 and $380 \mathrm{~nm}$ by employing $10 \mathrm{~nm}$ wide filters centered at the wavelengths of interest (Chroma Technology Corp.). The emitted light at $485-540 \mathrm{~nm}$ was collected by a cooled CCD camera (CoolsnapFx, Roper Scientific Inc.) through a $20 \times$ objective (Axiovert 200 microscope, Carl Zeiss, Inc.) at each excitation wavelength for $300 \mathrm{~ms}$. The fluorescence ratio within each cell was computed every second from the images obtained at the excitation wavelengths of 340 and 380 $\mathrm{nm}$ by subtracting the appropriate background fluorescence at each wavelength.

AFM Imaging. AFM experiments were performed with the samples in PBS using the AFM equipment (Bioscope SZ, Digital Instruments, Inc.) combined with an inverted optical microscope (TE2000-U, Nikon Corp.). The whole system is placed on an antivibration table and housed in a sound-proof cage to eliminate vibration and acoustic noise, respectively. A patch $(\sim 1 \times 1$ $\mu \mathrm{m}^{2}$ ) of plasma membrane was scanned by AFM in a tapping mode with 256 scan lines and 512 line samples at a scanning rate of $0.5 \mathrm{~Hz}$, of which the resonant frequency was set at 17 $\mathrm{kHz}$ with the amplitude setpoint of $0.6 \mathrm{~V}$, close to the target 

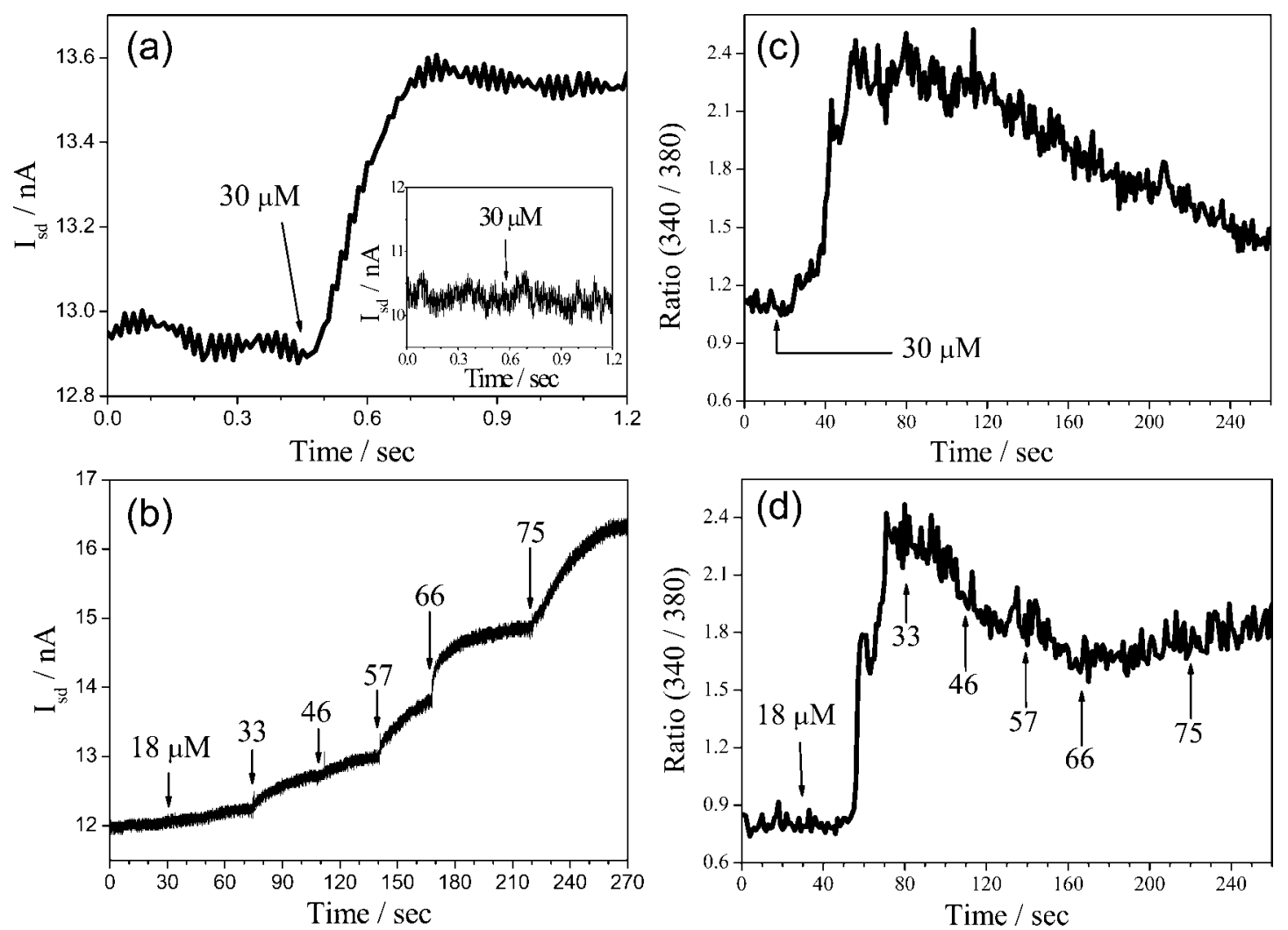

Figure 3. (a)-(b) Electric responses of $\mathrm{CgA} / \mathrm{SWCNT}-\mathrm{FET}$ to the $\mathrm{CgA}$ released from a living single chromaffin cell with histamine stimulations. (a) Current - time plot of the in situ detection of $\mathrm{CgA}$ released from a single chromaffin cell when the cell was stimulated by $30 \mu \mathrm{M}$ histamine. The inset depicts a control experiment without cell. Arrows indicate the addition of histamine. (b) Current-time plot of the concentration-dependent experiment with different histamine stimulations. (c) - (d) Changes in $\left[\mathrm{Ca}^{2+}\right]_{\mathrm{i}}$ represented by the fluorescence ratio of fura- 2 with the 340 and 380 $\mathrm{nm}$ excitations. The traces were averaged from 10 cells. (c) Averaged $\left[\mathrm{Ca}^{2+}\right]_{\mathrm{i}}$ response stimulated with $30 \mu \mathrm{M}$ histamine. (d) Averaged $\left[\mathrm{Ca}^{2+}\right]_{\mathrm{i}}$ responses with the same serial histamine stimulations as those in (b).

amplitude of $0.8 \mathrm{~V}$. The integral and proportional gains of the scanning parameters were $\sim 0.6$ and $\sim 1.2$, respectively. Silicon-nitride cantilevers with a normal force constant of 0.06 N/m (PNP-DB, NanoWorld) were mounted in the AFM fluid tip-holder and rinsed carefully with PBS before the tips were immersed into the cell samples in fluid.

Immunogold Labeling. Chromaffin cells were fixed by $3.7 \%$ formaldehyde in PBS for $30 \mathrm{~min}$ and then incubated in PBS containing $1 \%$ skim milk for $15 \mathrm{~min}$. Rabbit IgG against the N-terminal of synaptotagmin I (SytI) (S2177, Sigma-Aldrich Co.) was diluted in PBS (1:200) to stain the exposed SytI for $1 \mathrm{~h}$. After washing off extra IgG, cells was incubated in PBS containing $1 \%$ skim milk for another 15 min. PBS containing $30 \mathrm{~nm}$ gold particle tagged goat antirabbit IgG antibody (Ab27238, Abcam, 1:200 dilution) was used to label the stained SytI for $1 \mathrm{~h}$. After extra antibodies were washed off, cells were then fixed by $3.7 \%$ formaldehyde in PBS for another $30 \mathrm{~min}$ for AFM imaging experiments.

\section{Results and Discussion}

Exocytotic Release Detected by FET. CgA has been shown to be costored and coreleased with CA in chromaffin cells ${ }^{23}$ to control blood pressure. ${ }^{24}$ It is well-known that $\mathrm{Ca}^{2+}$ is the most important messenger to evoke cellular exocytosis. At resting, $\left[\mathrm{Ca}^{2+}\right]_{\mathrm{i}}$ is at $\sim 100 \mathrm{nM}$ and can increase to be higher than $1 \mu \mathrm{M}$ by different stimulations. The sources responsible for the elevation of $\left[\mathrm{Ca}^{2+}\right]_{\mathrm{i}}$ come from either intracellular $\mathrm{Ca}^{2+}$ stores or extracellular bath solution. In the exocytosis evoked with histamine, the activation of histaminergic $\mathrm{H}_{1} \mathrm{G}$ protein-coupled receptors on adrenal chromaffin cells will excite the phospho- lipase $\mathrm{C}$ to release $\mathrm{IP}_{3}$ (inositol 1,4,5-triphosphate) to the cytosol. The $\mathrm{IP}_{3}$ then binds to a specific receptor on the endoplasmic reticulum, from which the stored $\mathrm{Ca}^{2+}$ is released into the cytosol to evoke exocytosis. This mechanism responsible for the histamine-evoked exocytosis has been widely discussed. ${ }^{25,26}$ Alternatively, opening the voltage-gated $\mathrm{Ca}^{2+}$ channels on the plasma membrane by action potential or by changing the $\mathrm{K}^{+}$ gradient across the plasma membrane also allows the influx of $\mathrm{Ca}^{2+}$ into the cytosol to trigger exocytosis. ${ }^{27}$

In the in situ detection of the $\mathrm{CgA}$ released from a single chromaffin cell upon histamine stimulation, the $\mathrm{CgA}-\mathrm{Ab} /$ SWCNT-FET devices were covered with normal bath buffer (145 mM NaCl, $5 \mathrm{mM}$ glucose, $10 \mathrm{mM}$ Na-HEPES, $1 \mathrm{mM}$ $\mathrm{MgCl}_{2}, 5 \mathrm{mM} \mathrm{KCl}$, and $2.2 \mathrm{mM} \mathrm{CaCl}, \mathrm{pH} 7.3$ with $\mathrm{NaOH}$ ), as schematically illustrated in Figure 2a. Figure $3 \mathrm{a}$ shows the electric response of $\mathrm{CgA}-\mathrm{Ab} / \mathrm{SWCNT}-\mathrm{FET}$ in the cell experiment, where $I_{\mathrm{sd}}$ increased from 12.9 to $13.6 \mathrm{nA}$ when $30 \mu \mathrm{M}$ histamine was perfused into the chamber. This increase was not due to the nonspecific binding of histamine with $\mathrm{CgA}-\mathrm{Ab} /$ SWCNT-FET, because histamine alone in the absence of chromaffin cell had no effect on the FET conductivity as demonstrated in the inset of Figure 3a. Although the immunostaining images shown in Figure 1c were not sufficient to demonstrate that $\mathrm{CgA}$ is stored in the $\mathrm{SV}$, the increase in the conductivity of $\mathrm{CgA}-\mathrm{Ab} / \mathrm{SWCNT}-\mathrm{FET}$ revealed that $\mathrm{CgA}$ was released from a stimulated chromaffin cell. These results indicate that the sensitivity of $\mathrm{CgA}-\mathrm{Ab} / \mathrm{SWCNT}-\mathrm{FET}$ is high enough to detect the release of $\mathrm{CgA}$ from a single chromaffin cell. Furthermore, Figure $3 \mathrm{~b}$ shows that the change of FET conductivity increases with the concentrations $(18,33,46,57,66$, and 

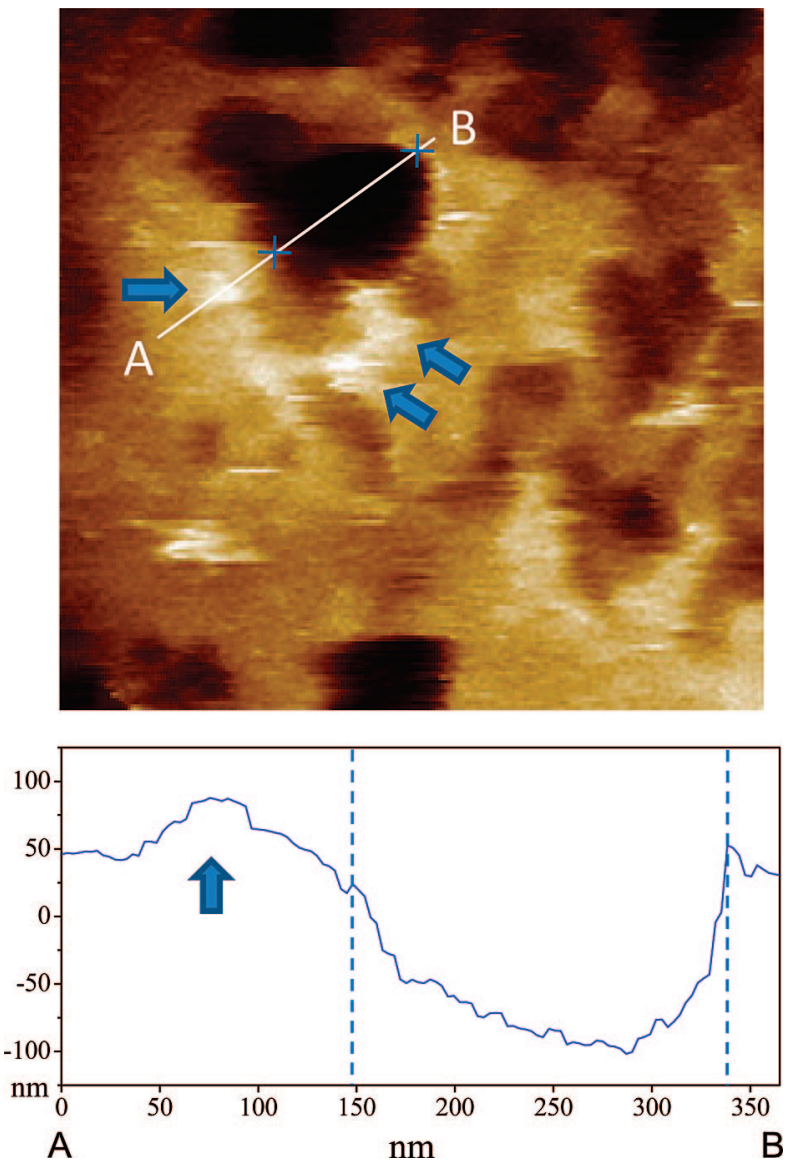

Figure 4. (Upper) AFM image of the depression on the surface of a chromaffin cell under high- $\mathrm{K}^{+}$buffer stimulation. The chromaffin cell was fixed and stained with antibody against SytI, which was identified by AFM imaging with assistance of the labeling 30-nm gold particle tagged second antibody. Arrows indicate the gold nanoparticles, which help to locate a depression (in dark brown color). (Lower) Cross-section analysis, along the white line AB drawn in the upper AFM image, for the depression and a $30 \mathrm{~nm}$ gold particle. The width of the depression is $190 \mathrm{~nm}$ marked between two dash lines. The height $(\sim 30 \mathrm{~nm})$ of a gold nanoparticle is pointed by an arrow.

$75 \mu \mathrm{M})$ of added histamine, suggesting that our $\mathrm{CgA}-\mathrm{Ab} /$ SWCNT-FET can discriminate the amount of $\mathrm{CgA}$ release depending on the strength of the stimulation.

Because of its low isoelectric point $(\mathrm{p} I=4.5-5), \mathrm{CgA}$ is negatively charged in normal bath buffer at $\mathrm{pH}$ 7.3. Therefore, the binding of $\mathrm{CgA}$ to $\mathrm{CgA}-\mathrm{Ab} / \mathrm{SWCNT}$-FET should enhance the conductivity in the p-type semiconductive device due to an electrostatic gating effect. Furthermore, it has been reported that the amount of exocytotic $\mathrm{CgA}$ is proportional to the $\mathrm{CA}$ released from chromaffin cells. ${ }^{28}$ Accordingly, the detected amount of $\mathrm{CgA}$ reflects that of $\mathrm{CA}$ release. ${ }^{28}$ It was also shown in the dose response curve that the level of CA release, evoked with histamine, does not reach plateau even after $5 \mathrm{~h}$ stimulation, and the response is not saturated until $100 \mu \mathrm{M}$. In this study, we have tested the $\left[\mathrm{Ca}^{2+}\right]_{\mathrm{i}}$ responses in a chromaffin cell by fura-2 fluorescence ratio. In Figure $3 \mathrm{c}$, the addition of $30 \mu \mathrm{M}$ histamine to chromaffin cells quickly induced an elevation in $\left[\mathrm{Ca}^{2+}\right]_{\mathrm{i}}$, which then decreased slowly to a basal level. In comparison, Figure $3 \mathrm{~d}$ shows the response of $\left[\mathrm{Ca}^{2+}\right]_{\mathrm{i}}$ to a series of histamine stimulations, where the addition of $18 \mu \mathrm{M}$ histamine did not induce immediately a significant elevation in $\left[\mathrm{Ca}^{2+}\right]_{\mathrm{i}}$ but with a delay. Afterward, the $\left[\mathrm{Ca}^{2+}\right]_{\mathrm{i}}$ quickly reached a maximum and declined slowly but remained at a level higher than the basal no matter how high the concentration of histamine was further increased. These fura-2 fluorescence ratio experiments explain the FET results (Figure 3b) why there was no much $\mathrm{CgA}$ detected under $18 \mu \mathrm{M}$ histamine stimulation; afterward, the $\left[\mathrm{Ca}^{2+}\right]_{\mathrm{i}}$ was kept at a high level to allow more
$\mathrm{CgA}$ release in the subsequent histamine stimulations. In view of the report that higher concentration of histamine can increase the rate of CA release, ${ }^{29}$ we observed consistently the release of $\mathrm{CgA}$ in a faster rate to reach equilibrium under the continuous increases of histamine concentration (see the horizontal $I_{\text {sd }}$ level is more quickly reached in the higher histamine concentrations as shown in Figure $3 b$ ), although the $\left[\mathrm{Ca}^{2+}\right]_{i}$ was not significantly enhanced during the serial stimulations (Figure 3d). These results indicate that the $\mathrm{CgA}-\mathrm{Ab} / \mathrm{SWCNT}-\mathrm{FET}$ can respond to different levels of $\mathrm{CgA}$ release.

Although the surface of nanotube is tiny and the interaction between $\mathrm{CgA}$ and $\mathrm{CgA}-\mathrm{Ab}$ is strong, the FET device is not easily saturated as its conductance kept escalating when histamine concentration was increasingly added. On the basis of these tests, our system is well appropriate for detecting the release of proteins from a single excitable cell with high sensitivity. Furthermore, in the exocytosis of chromaffin cells with $100 \mu \mathrm{M}$ histamine stimulation in $15 \mathrm{~min},{ }^{30}$ it has been reported that $10 \%$ of CA stored in the cell can be released, which is equivalent to $\sim 17 \mathrm{fmol} .{ }^{31}$ According to the study that the amount of $\mathrm{CgA}$ released is much less than $\mathrm{CA},{ }^{32}$ this hints that less than 1 fmol of $\mathrm{CgA}$ could be detected by our SWCNTFET.

Fusion Pores Imaged by AFM. In the observation of possible fusion pores by AFM, the antibody against the $\mathrm{N}$-terminal of SytI was chosen to label the formaldehydefixed chromaffin cells. SytI is a vesicle transmembrane protein with $\mathrm{N}$-terminal in the lumen of the vesicle. When fused with 

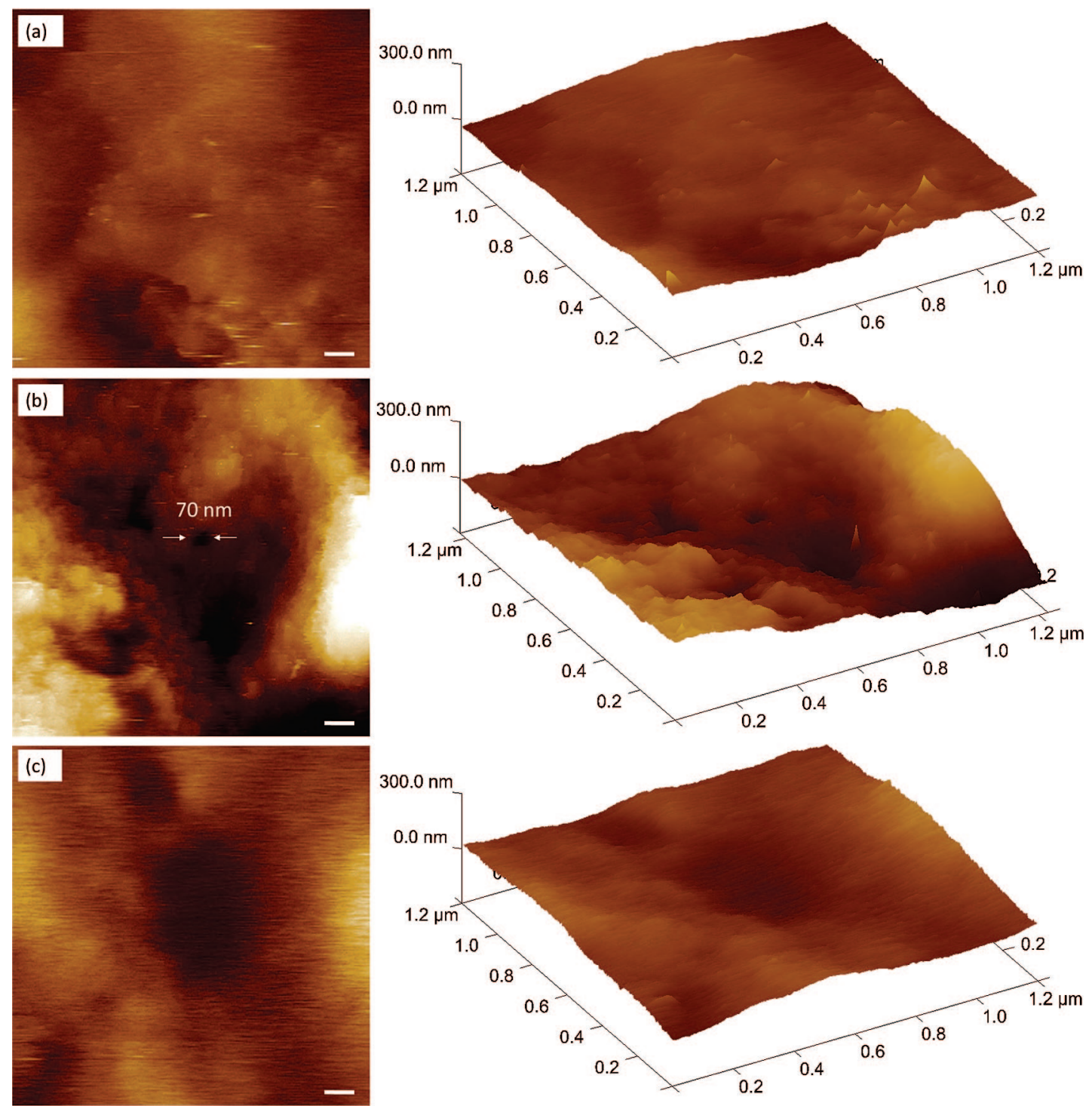

Figure 5. AFM images for fixed chromaffin cells with different stimulations. (a) Control cell without stimulation. (b) Cell stimulated with $30 \mu \mathrm{M}$ histamine for $2 \mathrm{~min}$ and then fixed. (c) Cell pretreated with $10 \mu \mathrm{M}$ mepyramine for $15 \mathrm{~min}$ and then stimulated with $10 \mu \mathrm{M}$ histamine for 2 min. The scale bars are $100 \mathrm{~nm}$. Shown on the right side are their corresponding 3D images.

plasma membrane, this $\mathrm{N}$-terminal will be exposed to the extracellular surface and be recognized by this antibody. For ease of detection, the antibody against SytI was further conjugated with the second antibody tagged by $30 \mathrm{~nm}$ gold particle, which will later serve as a marker for the AFM imagings. To evoke cellular exocytosis, chromaffin cells were treated with high- $\mathrm{K}^{+}$buffer $(54 \mathrm{mM})$ to open the voltagegated $\mathrm{Ca}^{2+}$ channels and were subsequently labeled with the antibody against SytI. Figure 4 depicts a representative AFM image of a depression surrounded by three gold nanoparticles (marked by arrows). A cross-section analysis indicates that the width of this depression is $\sim 190 \mathrm{~nm}$ and the gold nanoparticles are elevated by about $30-50 \mathrm{~nm}$ above the cellular surface. The gold nanoparticles are two-antibody away from the labeled SytI proteins; its location may not directly reflect the location of vesicle fusion but must be very close because the size of an antibody is no more than 10 nm. Furthermore, such elevations caused by immunogold could not be identified in the cells without high- $\mathrm{K}^{+}$stimulation (data not shown) and no such elevations accompanied the depression were found in scanned patches without immunogold labeling (Figures 5 and 6). These results suggest that the depression is where the fusion occurs.
To characterize how the fusion pores would be modulated by different secretagogues, chromaffin cells were first stimulated with histamine for 2 min and then fixed with $3.7 \%$ formaldehyde for AFM scanning (Figure 5). For a comparative study, Figure 5a shows the surface of a typical cell without stimulation, which is rough with small fluctuations. After histamine treatment, several deep depressions were frequently identified in each of the membrane patches scanned (Figure 5b). In contrast, the number of depressions was reduced by treating the cell with mepyramine, an $\mathrm{H}_{1}$ receptor antagonist, ${ }^{33}$ before histamine application (Figure $5 \mathrm{c}$ ). These differences suggest that the surface depressions, stimulated with histamine, are due to the activation of $\mathrm{H}_{1} \mathrm{G}$ proteincoupled receptor pathway for the elevation of $\left[\mathrm{Ca}^{2+}\right]_{i}$ to trigger exocytosis.

It is unlikely that such depressions were randomly produced. When the histogram of surface heights in all of the scanned membrane patches are plotted, either stimulated or untreated, there is no significant difference in the height distribution (Supporting Information S1 and S2). These measurements indicate that the overall membrane fluctuation was not altered regardless of the stimulation. Nevertheless, the depressions at some specific locations have big local 

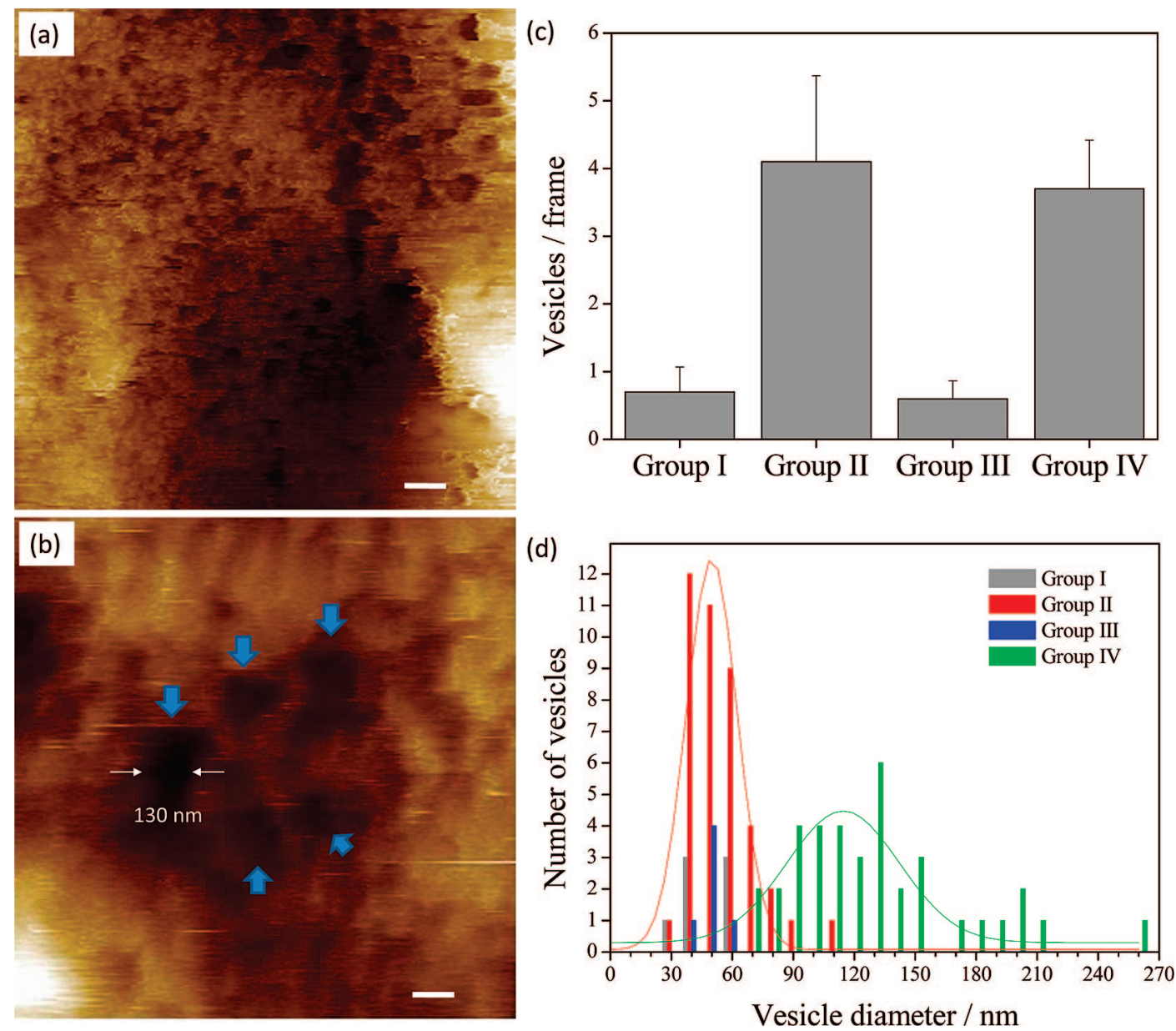

Figure 6. Different pore sizes with different stimulations obtained by AFM imaging. The cells were stimulated with histamine (group II), mepyraminepretreated before histamine stimulation (group III), high- $\mathrm{K}^{+}$buffer (group IV), or without stimulation (group I), and then fixed for AFM scanning. (a) Group II cell with lots of depressions. The scale bar is $100 \mathrm{~nm}$. (b) Group IV cell with 5 depressions indicated by arrows. The leftmost depression is estimated to be formed from a vesicle of $130 \mathrm{~nm}$ in diameter. The scale bar is $100 \mathrm{~nm}$. (c) Averaged number of vesicles/depressions per AFM scanning frame. Only depressions with depth and width over 20 and $30 \mathrm{~nm}$, respectively, were counted as fusion pores. Data presented are mean \pm SEM from 10 scanning frames in each group. (d) Histogram of the estimated vesicle diameters. The data are fitted with Gaussian distribution functions to estimate the vesicle diameters (red, group II; green, group IV). The center of the distribution indicates the averaged vesicle diameter of 50 and $115 \mathrm{~nm}$ for groups II and IV, respectively.

fluctuations. In addition, such depressions could be blocked by mepyramine, which further confirms that the occurrence of such depressions is due to the evoked-exocytosis via the $\mathrm{H}_{1}$ receptor pathway.

It has been suggested that the vesicle fusion onto the plasma membrane can be either kiss-and-run or full-collapse depending on the stimulation level. Both mechanisms have been identified in bovine chromaffin cells. ${ }^{34}$ To characterize the difference in the depressions elicited by either histamine or high- $\mathrm{K}^{+}$stimulation, the width and depth of the depressions obtained from the AFM images were analyzed (Figure 6). Four groups of chromaffin cells were prepared for the AFM scans: group I, cells without any treatment; group II, cells were stimulated with $10 \mu \mathrm{M}$ histamine for 5 min; group III, cells were pretreated with $10 \mu \mathrm{M}$ mepyramine for $20 \mathrm{~min}$ and then stimulated by $10 \mu \mathrm{M}$ histamine for 5 min; group IV, cells were stimulated with high- $\mathrm{K}^{+}$buffer in the presence of $3.7 \%$ formaldehyde for $2 \mathrm{~min}$. After these treatments, the cells of groups I-IV were all fixed with $3.7 \%$ formaldehyde in PBS for $30 \mathrm{~min}$.

The AFM images (or frames) of each group were sampled in several randomly selected surface regions of $1.2 \times 1.2 \mu \mathrm{m}^{2}$ from different cells. In the measurements, only the depressions with depth and width over 20 and $30 \mathrm{~nm}$, respectively, were analyzed. In Figure 6a,b, the representative images show that depressions could be identified in the cells of groups II and IV stimulated with histamine and high- $\mathrm{K}^{+}$buffer, respectively, but not in those of groups I and III (Figure 5a,b). Figure 6a shows a hot-spot-like region on the plasma membrane, in which more depressions (thirteen depressions were counted within the criteria that the depressions with depth and width over 20 and $30 \mathrm{~nm}$, respectively) were observed than those in other images usually taken for group II. Figure 6c presents the averaged number of depressions per AFM scanning frame of $0.7 \pm 0.37,4.1 \pm 1.27$, $0.6 \pm 0.27$, and $3.7 \pm 0.72$, respectively, acquired from groups I-IV cells.

The observed concave depression patch is considered to come from the fusion of a spherical SV onto the plasma membrane. To estimate the vesicle diameter, a numerical volume integral is introduced

$$
\iint \sum_{i} z_{i} \mathrm{~d} x \mathrm{~d} y=\frac{4}{3} \pi R^{3}
$$

where $\mathrm{d} x=(\operatorname{scan}$ size $) /($ line samples $)=2.34 \mathrm{~nm}, \mathrm{~d} y=($ scan size $) /($ scan line $)=4.69 \mathrm{~nm}, z_{i}$ is the height for the area element of $\mathrm{d} x \cdot \mathrm{d} y$ within a depression, and $R$ is the radius of the calculated vesicle. Figure $6 \mathrm{~b}$ shows that there are five depres- 
sions within a large "pit". The diameters calculated from the volume integral are $130 \mathrm{~nm}$ for the largest depression and $\sim 60-90 \mathrm{~nm}$ for the others. Figure 6d displays Gaussian-profile fittings to the histograms of the estimated vesicle diameters with peak center $\left(X_{\mathrm{c}}\right)$ and peak width $(w)$ of $\left(X_{\mathrm{c}}, w\right)=(49.9 \pm 0.9$ $\mathrm{nm}, 12.5 \pm 0.9 \mathrm{~nm})$ and $(114.5 \pm 3.9 \mathrm{~nm}, 27.6 \pm 4.6 \mathrm{~nm})$ for the cells stimulated with histamine and high- $\mathrm{K}^{+}$buffer, respectively. These results demonstrate that different stimulations evoke different size-distributions of vesicles in the exocytosis.

Our results reveal that AFM can be used to monitor the occurrence of exocytosis and to discriminate various pore-size distributions of the fused vesicles under different stimulations. Previous studies suggest that the $\mathrm{Ca}^{2+}$ influx coming through $\mathrm{Ca}^{2+}$ channels has a better efficacy to induce vesicle fusion than those from intracellular $\mathrm{Ca}^{2+}$ stores ${ }^{35}$ and the vesicles tend to proceed full-collapse fusion under high $\left[\mathrm{Ca}^{2+}\right]_{\mathrm{i}}{ }^{34}$ The $\left[\mathrm{Ca}^{2+}\right]_{\mathrm{i}}$ elevated by high- $\mathrm{K}^{+}$buffer remains at a higher level compared to that stimulated by histamine (data not shown). Therefore, the difference in size-distributions of the estimated vesicle sizes (Figure 6) may reflect different modes (full-collapse or kissand-run) involved in the vesicle fusion depending on the level of $\left[\mathrm{Ca}^{2+}\right]_{\mathrm{i}}$ elevation.

There are two main vesicle types verified by electron microscopy in chromaffin cells, large dense core vesicle (LDCV) and SV with diameters of $\sim 200$ and $\sim 50 \mathrm{~nm}$, respectively. ${ }^{11,36,37}$ The vesicle sizes we estimated are close to those obtained from electron microscopic results. However, the fused vesicles might not have fully dilated and are still in $\Omega$-shape, suggesting that the observed AFM images may underestimate the vesicle sizes. Alternatively, the depressions obtained by AFM might be endocytotic pits, because the cells used in this study were fixed. This is difficult to discriminate unless the experiments were done in live cells. However, the results obtained from live pancreatic $\beta$-cells have also shown similar depression sizes, ${ }^{18}$ supporting that the depressions we observed should be due to exocytosis. In the report using capacitance measurement to reflect the changes in cell size due to the occurrence of exocytosis and endocytosis which increase and decrease the cell size, respectively, the capacitance continues increasing during the period of histamine stimulation; in contrast, the capacitance increases during the membrane depolarization and recovers to resting level afterward. ${ }^{21}$ This measurement elucidates that endocytosis is not significant or may not even occur during histamine stimulation. Comparatively, endocytosis occurs when the cells are depolarized by high- $\mathrm{K}^{+}$stimulation but might be blocked by the addition of formaldehyde, which was used to fix the cells in this experiment. Therefore, it is unlikely that the depressions observed are due to endocytosis.

\section{Conclusions}

In summary, we have demonstrated the successful applications of SWCNT-FET and AFM to detect, respectively, the tiny amount of $\mathrm{CgA}$ release and the small fusion pores in single chromaffin cells. Furthermore, CgA-Ab/SWCNT-FET can discriminate the amounts of $\mathrm{CgA}$ release evoked with different levels of stimulation. The membrane surfaces obtained by AFM imaging indicate that depressions occur much more frequently in the stimulated cells than those without stimulation. The SV sizes estimated from the AFM images are different with high- $\mathrm{K}^{+}$buffer and histamine stimulations. This work demonstrates that AFM can provide insights into the fundamental properties of exocytosis in neuroendocrine cells. In addition to many merits of SWCNT-
FET and AFM as powerful techniques, the most advantage of applying these tools for biological research is that they are noninvasive to the cells, which can be kept intact with minimal perturbation during the investigations. In the future, live-cell monitoring will be adopted to capture the exocytotic scenes in real time and to characterize how this pore formation is modulated by different proteins.

Acknowledgment. This work is supported in part by National Science Council of Taiwan, ROC, under Grant Nos. NSC952320-B-002-060, NSC95-2113-M-001-034-MY3, and NSC952627-M-002-003.

Supporting Information Available: Discussion of the surface roughness of cells is available free of charge via the Internet at http://pubs.acs.org.

\section{References and Notes}

(1) Garcia, A. G.; Garcia-de-Diego, A. M.; Gandia, L.; Borges, R.; Garcia-Sancho, J. Physiol. Rev. 2006, 86, 1093-1131.

(2) Südhof, T. C. Аnnu. Rev. Neurosci. 2004, 27, 509-547.

(3) Chen, R. J.; Choi, H. C.; Bangsaruntip, S.; Yenilmez, E.; Tang, X. W.; Wang, Q.; Chang, Y. L.; Dai, H. J. J. Am. Chem. Soc. 2004, 126, $1563-1568$.

(4) Grüner, G. Anal. Bioanal. Chem. 2006, 384, 322-335.

(5) Wang, C. W.; Pan, C. Y.; Wu, H. C.; Shih, P. Y.; Tsai, C. C.; Liao, K. T.; Lu, L. L.; Hsieh, W. H.; Chen, C. D.; Chen, Y. T. Small 2007, 3, 1350-1355.

(6) Patolsky, F.; Timko, B. P.; Yu, G. H.; Fang, Y.; Greytak, A. B.; Zheng, G. F.; Lieber, C. M. Science 2006, 313, 1100-1104.

(7) Li, C.; Curreli, M.; Lin, H.; Lei, B.; Ishikawa, F. N.; Datar, R.; Cote, R. J.; Thompson, M. E.; Zhou, C. W. J. Am. Chem. Soc. 2005, 127, 12484-12485.

(8) Patolsky, F.; Zheng, G.; Lieber, C. M. Nat. Protocols 2006, 1, 17111724.

(9) Cui, Y.; Wei, Q. Q.; Park, H. K.; Lieber, C. M. Science 2001, 293, $1289-1292$.

(10) Taupenot, L.; Harper, K. L.; O’Connor, D. T. N. Engl. J. Med. 2003, 348, 1134-1149.

(11) Grabner, C. P.; Price, S. D.; Lysakowski, A.; Fox, A. P. J. Neurophysiol. 2005, 94, 2093-2104.

(12) Westerink, R. H. S. Neurotoxicology 2004, 25, 461-470.

(13) Cornea, A.; Janovick, J. A.; Lin, X. W.; Conn, P. M. Endocrinology 1999, 140, 4272-4280.

(14) Holt, M.; Cooke, A.; Neef, A.; Lagnado, L. Curr. Biol. 2004, 14, 173-183.

(15) Cho, S. J.; Quinn, A. S.; Stromer, M. H.; Dash, S.; Cho, J.; Taatjes, D. J.; Jena, B. P. Cell Biol. Int. 2002, 26, 35-42.

(16) Cho, S. J.; Jeftinija, K.; Glavaski, A.; Jeftinija, S.; Jena, B. P.; Anderson, L. L. Endocrinology 2002, 143, 1144-1148.

(17) Cho, S. J.; Wakade, A.; Pappas, G. D.; Jena, B. P. Ann. N.Y. Acad. Sci. 2002, 971, 254-256.

(18) Schneider, S. W.; Sritharan, K. C.; Geibel, J. P.; Oberleithner, H.; Jena, B. P. Proc. Natl. Acad. Sci. U.S.A. 1997, 94, 316-321.

(19) Jena, B. P.; Cho, S. J.; Jeremic, A.; Stromer, M. H.; Abu-Hamdah, R. Biophys. J. 2003, 84, 1337-1343.

(20) Südhof, T. C. Nature 1995, 375, 645-653.

(21) Pan, C. Y.; Jeromin, A.; Lundstrom, K.; Yoo, S. H.; Roder, J.; Fox, A. P. J. Neurosci. 2002, 22, 2427-2433.

(22) Payan-Carreira, R.; Rodrigues, P.; Carvalho, P. R. F. Anim. Reprod. Sci. 2006, 96, 146-153.

(23) O'Connor, D. T.; Frigon, R. P. J. Biol. Chem. 1984, 259, $3237-$ 3247.

(24) Mahapatra, N. R.; O'Connor, D. T.; Vaingankar, S. M.; Hikim, A. P. S.; Mahata, M.; Ray, S.; Staite, E.; Wu, H. J.; Gu, Y. S.; Dalton, N.; Kennedy, B. P.; Ziegler, M. G.; Ross, J.; Mahata, S. K. J. Clin. Invest. 2005, 115, 1942-1952.

(25) Marley, P. D. Pharmacol. Ther. 2003, 98, 1-34.

(26) Bunn, S. J.; Dunkley, P. R. Clin. Exp. Pharmacol. P. 1997, 24, 624-631.

(27) Yuan, X. J. Circ. Res. 1995, 77, 370-378.

(28) Dimsdale, J. E.; O'Connor, D. T.; Ziegler, M.; Mills, P. Life Sci. 1992, 51, 519-525.

(29) Noble, E. P.; Bommer, M.; Liebisch, D.; Herz, A. Biochem. Pharmacol. 1988, 37, 221-228.

(30) Bunn, S. J.; Boyd, T. L. J. Neurochem. 1992, 58, 1602-1610.

(31) Tomlinson, A.; Durbin, J.; Coupland, R. E. Neuroscience 1987, 20, 895-904. 
(32) O'Connor, D. T.; Klein, R. L.; Thuresonklein, A. K.; Barbosa, J. A. Brain Res. 1991, 567, 188-196.

(33) Fitzsimons, C. P.; Monczor, F.; Fernández, N; Shayo, C.; Davio, C. J. Biol. Chem. 2004, 279, 34431-34439.

(34) Elhamdani, A.; Azizi, F.; Artalejo, C. R. J. Neurosci. 2006, 26, 3030-3036.

(35) Schneggenburger, R.; Neher, E. Curr. Opin. Neurobiol. 2005, 15, 266-274.
(36) Navone, F.; Jahn, R.; Digioia, G.; Stukenbrok, H.; Greengard, P.; Decamilli, P. J. Cell Biol. 1986, 103, 2511-2527.

(37) Darchen, F.; Senyshyn, J.; Brondyk, W. H.; Taatjes, D. J.; Holz, R. W.; Henry, J. P.; Denizot, J. P.; Macara, I. G. J. Cell Sci. 1995, 108, $1639-1649$.

JP803000A 


\section{Supporting Information}

\section{Exocytosis of a Single Bovine Adrenal Chromaffin Cell: The Electrical and Morphological Studies}

Chia-Chang Tsai, ${ }^{1}$ Chih-Cheng Yang, ${ }^{2}$ Po-Yuan Shih, ${ }^{2}$ Cen-Shawn Wu, ${ }^{3}$ Chii-Dong Chen, ${ }^{4}$ Chien-Yuan Pan, ${ }^{2}$ and Yit-Tsong Chen ${ }^{1,5} *$

1 Institute of Atomic and Molecular Sciences, Academia Sinica, P.O. Box 23-166, Taipei 106, Taiwan

2 Department of Life Science and Institute of Zoology, National Taiwan University, Taipei 106, Taiwan

3 Department of Physics, National Changhua University of Education, Jin-De Campus, Changhua 500, Taiwan

4 Institute of Physics, Academia Sinica, Nankang, Taipei 115, Taiwan

5 Department of Chemistry, National Taiwan University, Taipei 106, Taiwan

E-mail: cypan@ntu.edu.tw or ytchen@pub.iams.sinica.edu.tw 


\section{S1. No significant difference in the surface roughness of cells}

Figure S1 shows the height distributions analyzed from the acquired AFM images (or frames) for Groups I-IV. The horizontal axis indicates the height (z) of an area pixel $(\Delta x \cdot \Delta y)$ in each scanned AFM 3D image, where the height was divided into 500 categories between the highest and lowest pixels. Statistically, height $=0$ corresponds to the average surface roughness of the cell. The vertical axis represents the number percentage of each area pixel $(256 \times 512$ pixels in total) that falls into the 500 height categories. In the AFM imaging experiments, ten frames have been scanned for each Group. In Figures S1a-d, ten curves with different colors depict the height distributions analyzed from the ten obtained AFM frames. The results from statistical analysis show that the height distributions in the acquired AFM images for Groups I-IV are not significantly different as will be discussed in the following section $\mathrm{S} 2$.
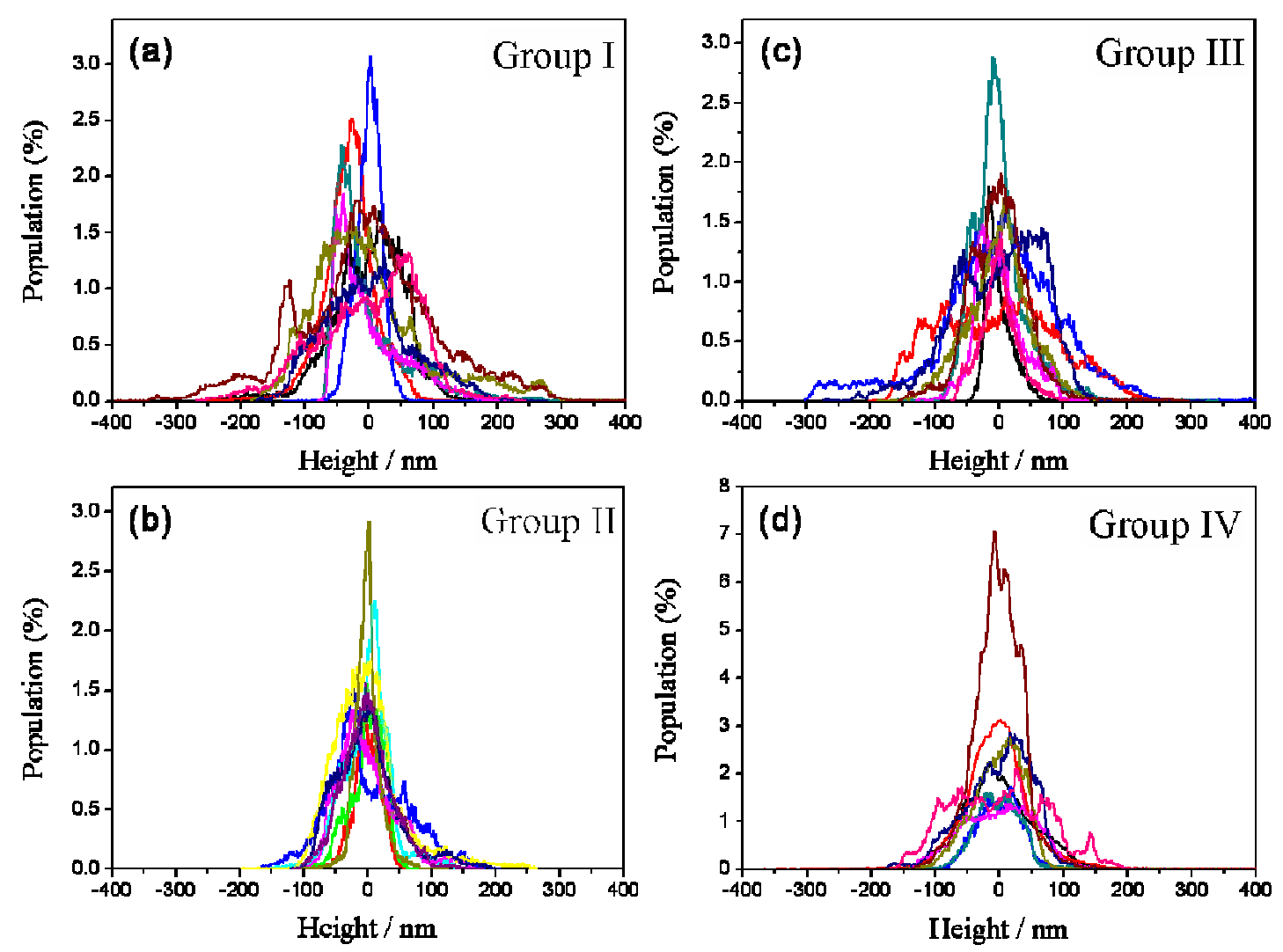

Figure S1. Height distributions analyzed from the obtained AFM images (or frames) of Groups I-IV. 


\section{S2. Statistic analysis for the surface roughness of cells}

The height distributions in Figure S1 were further fitted into Gaussian distribution function:

$$
y=y_{0}+A e^{-\frac{\left(x-\mathrm{X}_{c}\right)^{2}}{2 \mathrm{~W}^{2}}}
$$

where $\mathrm{X}_{c}$ represents the peak center and $\mathrm{W}$ is the peak width of the Gaussian profile. The mean values of $\mathrm{X}_{\mathrm{c}}$ and $\mathrm{W}$ per AFM image for Groups I-IV were analyzed as displayed in Figure S2. The error bars indicate the standard errors. According to the results of one-way ANOVA analysis, the height distributions for Groups I-IV have no significant difference.
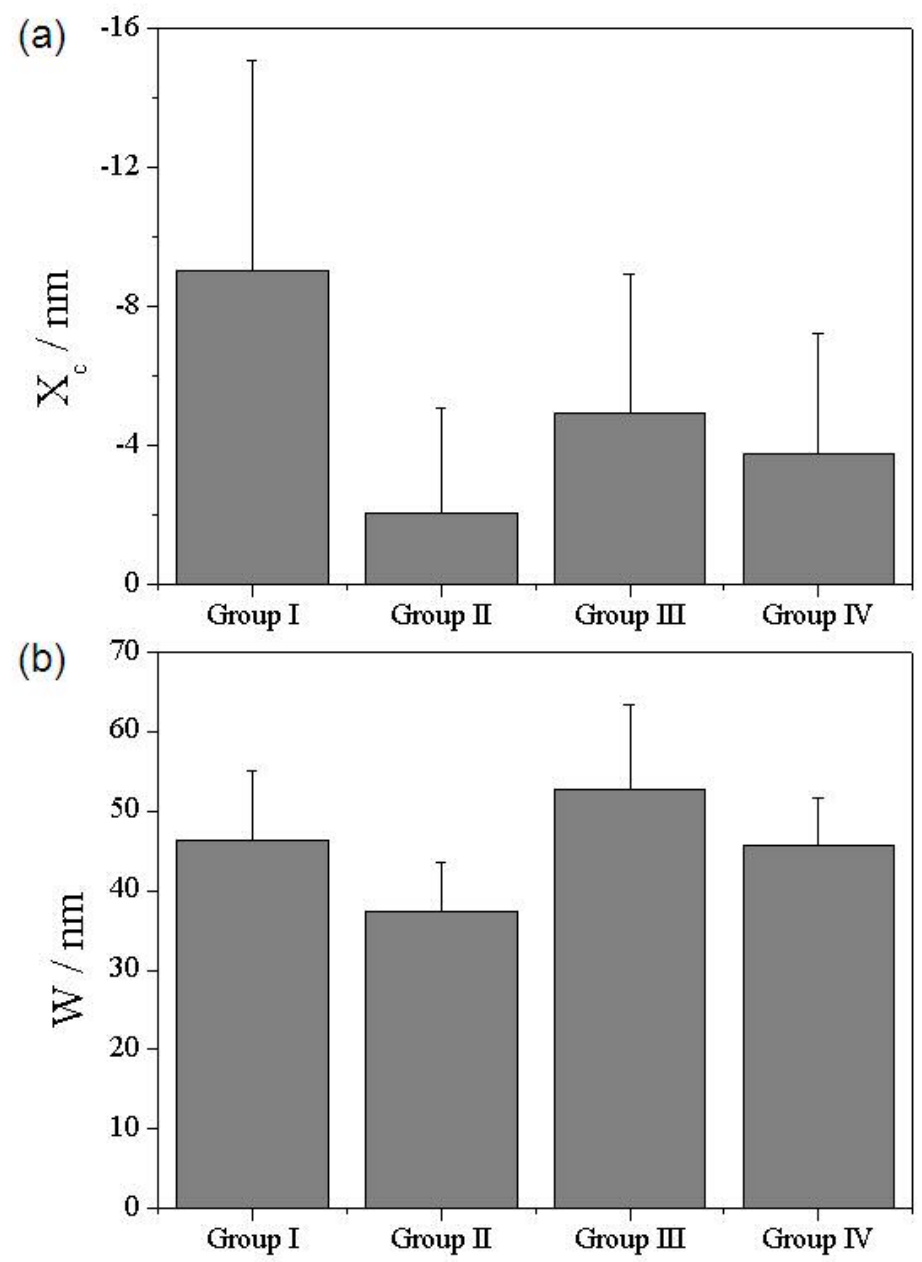

Figure S2. Statistic analysis for the peak centers $\left(\mathrm{X}_{c}\right)$ and peak widths $(\mathrm{W})$ averaged from the obtained AFM images of Groups I-IV. The histograms show the mean values of (a) peak center and (b) peak width in the Gaussian distribution. 